\title{
Risk Perception and Management Strategies in Dairy Farming: A Case of Adana Province of Turkey
}

\author{
Seyit Hayran*, Aykut Gül
}

Department of Agricultural Economics, Faculty of Agriculture, Çukurova University, 01330 Adana, Turkey

\section{A R T I C LE IN F O}

\section{Article history:}

Received 10 November 2015

Accepted 23 November 2015

Available online, ISSN: 2148-127X

\section{Keywords.}

Risk

Risk perception

Dairy farming

Adana

Turkey

\section{* Corresponding Author:}

E-mail: shayran@cu.edu.tr

\begin{abstract}
A B S T R A C T
This study aims to determine and analyse farmers' risk perceptions and risk management strategies in dairy farming. Data were obtained in 2014 (December) and 2015 (February and March) from face-to-face interviews with 96 dairy farmers in Yüregir and Saricam district of Adana province of Turkey. Factor analysis was used in data reduction to identify a small number of factors related to risk sources and risk strategies in this study. Then, multiple regression model was used to evaluate the influence of socio-economic characteristics and communication behaviour on the farmers' risk perceptions and risk management strategies using factor loadings. The results of this study show that the most important risk source that the farmers' perceive is variability in feed prices and risk management strategy that the farmers' perceive is take precautions to prevent disease. The results of factor analysis show that the risk scale consists of 8 factors explaining $70.24 \%$ of total variance. The internal consistency coefficient Cronbach Alfa of the scale is 0.808 and $\mathrm{KMO}$ is 0.732 . The risk management scale consists of 6 factors explaining $67.78 \%$ of total variance. The internal consistency coefficient Cronbach Alfa of the scale is 0.775 and $\mathrm{KMO}$ is 0.746 . According to the results, perceptions were farmer-specific, a number of socio-economic variables and communication behaviour are found to be related to risk and risk management. To improve risk management strategies is useful for farmers as well and might help them to avoid many risks and reduce losses.
\end{abstract}

Türk Tarım - Gıda Bilim ve Teknoloji Dergisi, 3(12): 952-961, 2015

\section{Süt Sığırcılığında Risk Algıları ve Yönetim Stratejileri: Türkiye'nin Adana İli Örneği}

\section{A K A L E B İ L G İ S İ}

Geliş 10 Kasım 2015

Kabul 23 Kasım 2015

Çevrimiçi baskı, ISSN: 2148-127X

Anahtar Kelimeler:

Risk

Risk algis1

Süt sı̆̆ırcilı̆̆ 1

Adana

Türkiye

\section{* Sorumlu Yazar:}

E-mail: shayran@cu.edu.tr

\section{Ö Z E T}

Bu çalışma süt sığırcılığında çiftçilerin risk algıları ve risk yönetim stratejilerini analiz etmeyi ve belirlemeyi amaçlamıştır. Veriler, Türkiye'nin Adana İli Yüreğir ve Sarıçam İlçelerinde rastgele belirlenen 96 süt sığırı yetiştiricisinden 2014 (Aralık) ve 2015 (Şubat ve Mart) yıllarında yüz yüze görüşme ile toplanmıştır. Risk kaynakları ve stratejilerini daha az sayıda değişkene indirgemek için faktör analizi kullanılmıştır. Ardından, sosyoekonomik değişkenler ve haberleşme davranışlarının çiftçilerin risk algıları ve yönetim stratejilerine etkilerini değerlendirmek için faktör yüklerinin bağımlı değişken olarak kullanıldığ ç̧oklu regresyon modeli kullanılmıştır. Çalışma sonuçları göstermiştir ki, çiftçi algılarına göre en önemli risk kaynağı yem fiyatlarındaki değişkenlik, en önemli risk yönetim stratejisi de hastalıklara karşı önceden önlem almaktır. Faktör analizi sonuçlarına göre, risk kaynakları ölçeği toplam varyansın \%70,24'ünü açıklayan 8 faktörden oluşmaktadır. Ölçeğin Cronbach Alfa değeri 0,808 ve KMO örneklem yeterlik ölçüsü 0,732 olarak hesaplanmıştır. Risk yönetim stratejileri ölçeği, toplam varyansın $\% 67,78$ 'ini açıklayan 6 faktörden oluşmaktadır. Ölçeğin Cronbach Alfa değeri 0,775 ve KMO örneklem yeterlik ölçüsü 0,775 olarak hesaplanmıştır. Araştırma sonuçlarına göre algılar çiftçilere özeldir, bir kısım sosyoekonomik değişkenler ve haberleşme davranışları risk ve risk yönetimi ile ilgili bulunmuştur. Risk yönetim stratejilerinin geliştirilmesi çiftçiler için faydalı olabilir ve bir kısım risklerden ve kayıplardan korunmalarını sağlayabilir. 


\section{Introduction}

Agricultural activities are carried out largely under the influence of natural conditions (Ceyhan, 2003). Farmers don't estimate their yield and income due to fluctuations in the factors they cannot control such as rains, temperature, disease, frost, wind, flood and so on. As a result of input-output price change, there are income fluctuation and important differences in agriculture year after year. As a result of this, farmers are forced to take risky decisions (Hazneci and Ceyhan, 2011). Farmers show different reactions and attitudes to changes, depending on the objectives and capital structure. It will be useful that analysis of the risks faced by farmers and their weight and determining of farmers' attitudes toward risk. Therefore when planning and in crop and livestock production, it is quite necessary that analysis of risks involved in agricultural production and understanding farmers' risk behaviours (Akcaoz and Ozkan, 2005; Hardaker et al., 2004; Hazneci and Ceyhan, 2011; Hoag, 2009).

Total milk production of Turkey was 16.5 million tons and Adana province's share $1.72 \%$ in 2013 (Anonim, 2015). Dairy farming is one of the most risky activities and showing quite rapid response to changing than other branches of agricultural production as result of inability to resolve the structural problems of agriculture, cannot be sufficiently improved domestic races, especially fluctuations in feed and milk prices, the continuity of labour demand, having cash needs constantly and regularly in Turkey similar to the world (Ceyhan et al., 2003; Gebreegziabher and Tadesse, 2014; Hazneci and Ceyhan, 2011; Kızılay, 2006; Zhou et al., 2012).

This study aims to determine and analyse farmers' risk perceptions and risk management strategies in dairy farming. And also it was examined that relationship between farmers' risk perception and socioeconomic variables / communication behaviour in the study. There are quite a large literature about dairy farmers' risk perception and understanding risk behaviour in the world (Flaten et al., 2005; Gebreegziabher and Tadesse, 2014; Meuwissen et al., 2001; Zhou et al., 2012) but limited in Turkey (Akcaoz et al., 2009; Kizllay, 2006). This study has attempted to fill this gap a little bit in Turkey.

\section{Materials and Methods}

Data were obtained in 2014 (December) and 2015 (February and March) from face-to-face interviews with 96 dairy farmers in Yüregir and Saricam district of Adana province in Turkey. In determining of the farmers which were included in survey, the following formula was used (Kaya et al., 2014).

$$
n=\left(\frac{\left(\frac{Z}{2}\right)}{d}\right)^{2} \cdot p \cdot q
$$

As determining sample volume, calculations were made by including the values for $10 \%$ margin error of $(d=0.10)$ and $95 \%$ confidential intervals $(Z=1.96)$, $\mathrm{q}=\mathrm{p}=0.50$ into the formula. According to these calculations, it was found that total 96 farmers should be interviewed.

In order to determine farmers' risk perception, they were presented and asked to rating according to their own perception risk and risk strategies statements which prepared in accordance with the five-point Likert scale (Agir et al., 2015; Akcaoz et al., 2010; Cukur et al., 2011). Farmers' risk perception was analysed using descriptive statistics and factor analysis. The large numbers of variables were reduced into smaller. This was done through factor analyses for sources of risk and risk management strategies. Factor analysis is a popular multivariate technique used to assess the variability of variables of a data-set (in our case, risk sources and risk management strategies variables) through linear combination of smaller number of latent variables, called factors. The extent of variation between variables in each factor is expressed by eigenvalues. If there is a strong relationship between variables, the first few factors explain a high proportion of the total variance and the last factors contain very little additional information. In our analysis, factors whose eigenvalues are greater than one were retained. Varimax rotation was used to maximize the variance of the squared loadings for each factor, and thus polarizes loadings (either high or low) on factors for easy interpretation. To check the internal reliabilities, we calculated Cronbach's alpha. Kaiser-Meyer-Olkin (KMO) measures of sampling adequacy for sources of risk and risk management strategies scale was calculated to check scales were adequate for factor analysis due to large portion of communality (Alpar, 2011; Hair et al., 1994; Kalayc1, 2008).

Multiple regression analysis was used to study examine relationship between farmers' risk perception and socioeconomic variables / communication behaviour (Agir et al., 2015; Alpar, 2011; Flaten et al., 2005; Hair et al., 1994; Kalayc1, 2008). Regression model was established according to the following general form.

$$
Y=\alpha_{0}+\beta X_{i} \ldots X_{n}+e_{i}
$$

In equality;

Y :Perception of risk and risk management strategies (as the factor scores)

$\mathrm{X}$ :Socioeconomic variables and communication behaviour.

\section{Results}

\section{Dairy Farmers' Socioeconomic Characteristics}

Farmers' socioeconomic characteristics examined by descriptive statistics like as frequency and percentage are presented in Table 1. According to the result, farmers are average 46.01 years old and their agricultural experience is 22.30 years but dairy farming experience is 26.04 years. Average farm size is 67.46 da. $16.67 \%$ of farmers have off-farm work and their education levels are shown in the Table 1. 


\section{Risk Sources in Dairy Farming}

Dairy farmers' perception of risk sources was examined using a scale contain of 27 items. The risk scale was prepared based on five-point Likert scale. In total, 27 sources of risk were presented to the respondents. Farmers were asked to score each source of risk on a Likert-scale from 1 (not important) to 5 (very important) to express how significant they considered each source of risk to be in terms of its potential impact on the economic performance of their farm. The first column of Table 2 shows average scores for all dairy farmers. The most important risk sources that the farmers' perceive were volatility in feed price (4.90), volatility in milk price (4.79), production diseases (4.72), misuse of drugs and other veterinary services (4.59) and epidemic animal diseases (4.57) (Table 2).

Dairy farmers' perceptions of the risks were evaluated by factor analysis. KMO measure of sampling adequacy was found to be 0.732 and the Bartlett Sphericity Test result was $p<0.001$. The internal consistency coefficient Cronbach Alfa of the scale was 0.808. These values showed that scale was suitable for factor analysis. As a result of factor analysis, the risk scale consists of 8 factors explaining $70.24 \%$ of total variance. These factors according to the factor loading were named "technology and cost", "production and marketing", "political and economic risks", "veterinary services and human resources", "price risk", "land value and insurance risks", "financial risks", and "feed shortage and low capacity", respectively (Table 3 ).

Factor 1. Technology and cost, loads significantly from technologic and cost variables like waste management, lack of technical knowledge, labour costs and changes in interest rates. Risk arising from activities as possibility of not marketing the milk, non-epidemic animal diseases, animal pests such as ticks, etc., epidemic animal diseases, likely to die of dairy cattle and production diseases variables indicates production and marketing risk in Factor 2. Significant loading of changes in government policy on animal health and welfare, changes in government support policies for dairy cattle, changes in the economic situation of Turkey and changes in consumer preferences reflects role of policy and economy in dairy farming because that Factor 3 was called political and economic risks. Factor 4 was called veterinary services and human resources because of the extremely high loadings of probability of lost key employee, misuse of drugs and other veterinary services and relationships between family members. Factor 5 was labelled as price risks because of the loadings milk price, meat price and feed price variables. Factor 6, Land value and insurance risks, loads significantly changes in land values and lack of insurance variables. Factor 7, Financial risks, loads credit availability and indebtedness and unable to repay debts variables. Factor 5 was labelled as feed shortage and low capacity because of the loadings inability to use modern technologies due to low capacity and low milk yield due to feed shortage variables (Table 3).

Result of this study indicates that dairy farmers consider milk price, feed price and production disease the most important risk factors affecting dairy farming. Gebreegziabher and Tadesse (2014) reported that low yields due to inadequate nutrition, poor agricultural income and lack of government support the most important risk factors affecting dairy farming in Ethiopia. Low milk yield due to feed shortage (4.07) and changes in government support policies for dairy cattle (4.49) identified as the important risk factors, but not yet the most important ranking among the top three risk sources in Adana. Milk price, corn prices (the most important feed ingredients used in dairy cattle in the study area) and the nonepidemic animal diseases were identified as the most important three sources of risk that another study conducted in China (Zhou et al., 2012). Milk price, health of family members and the lack of hygiene were identified the most important risk factors affecting dairy farming in Antalya province of Turkey (Akcaoz et al., 2009; Kizilay, 2006). The result of a study conducted in Norway by Flaten et al. (2005) indicated that dairy farmers perceive that changes in government support policy, changes in tax policy and milk prices were the most important sources of risk affecting their works. Taking into account findings from studies carried out in countries with different levels of development, dairy farmers' perceived milk price and feed price as the most important risk factors.

\section{Risk Management Strategies in Dairy Farming}

Dairy farmers' perception of risk management strategies was examined using a scale contain of 23 items. The risk management strategies scale was prepared based on five-point Likert scale. In total, 23 risk management strategies were presented to the respondents. Farmers were asked to score each risk management strategies on a Likert-scale from 1 (not important) to 5 (very important) to express how significant they considered each risk management strategies to be in terms of its potential impact on the economic performance of their farm. The first column of Table 4 shows average scores for all dairy farmers. The most important risk management strategies that the farmers' perceive were take precautions to prevent disease (4.66), to produce the lowest possible cost (ceteris paribus) (4.57), work with appropriate to climate conditions and highly efficient animal breeds (4.55) (Table 4).

Dairy farmers' perceptions of the risk management strategies were evaluated by factor analysis. KMO measure of sampling adequacy was found to be 0.746 and the Bartlett sphericity test result was $\mathrm{P}<0.001$, the internal consistency coefficient Cronbach Alfa of the scale was 0.775 . These values showed that scale was suitable for factor analysis. As a result of factor analysis, the risk scale consists of 6 factors explaining $67.78 \%$ of total variance. These factors according to the factor loading were named as "planning and insurance", "off-farm income and diversification of production", "flexibility and prudence", "farmer organization and income diversification", "cost reduction" and "labour division and consultancy", respectively (Table 5).

Factor 1, Planning and insurance, loads significantly from variables related to the planning and insurance as making insurance for animal, assets and personnel, dept management, applying strict hygiene rules, to collect market information, planning expenditure and diversification of products which supply to the market by farmer union. Significant loading of off-farm investment, to obtain non-farm income, make production in multiple 
fields and keeping farm record regularly reflect importance of risk management strategies related to income and diversification in dairy farming because that Factor 2 called off-farm income and diversification of production. Factor 3 was called flexibility and prudence because of extremely high loadings of keeping cash, work with modern machinery / equipment and take precautions to prevent disease. Factor 4 was labelled as farmer organization and income diversification because of the loadings make the crop production beside livestock, farmers union membership - cooperative partnership, family members working off-farm and family members working in other farms variables. Factor 5 was called cost reduction because of loadings to produce the lowest possible cost (ceteris paribus) and work with appropriate to climate conditions and highly efficient animal breeds variables. Significant loading of changes division of labour among family members, to participate in the extension service for dairy farmers and to benefit from technical consultancy services reflects role of labour division and extension because that factor 6 was labelled as labour division and consultancy (Table 5).

Table 1 Socioeconomic characteristics of dairy farmers

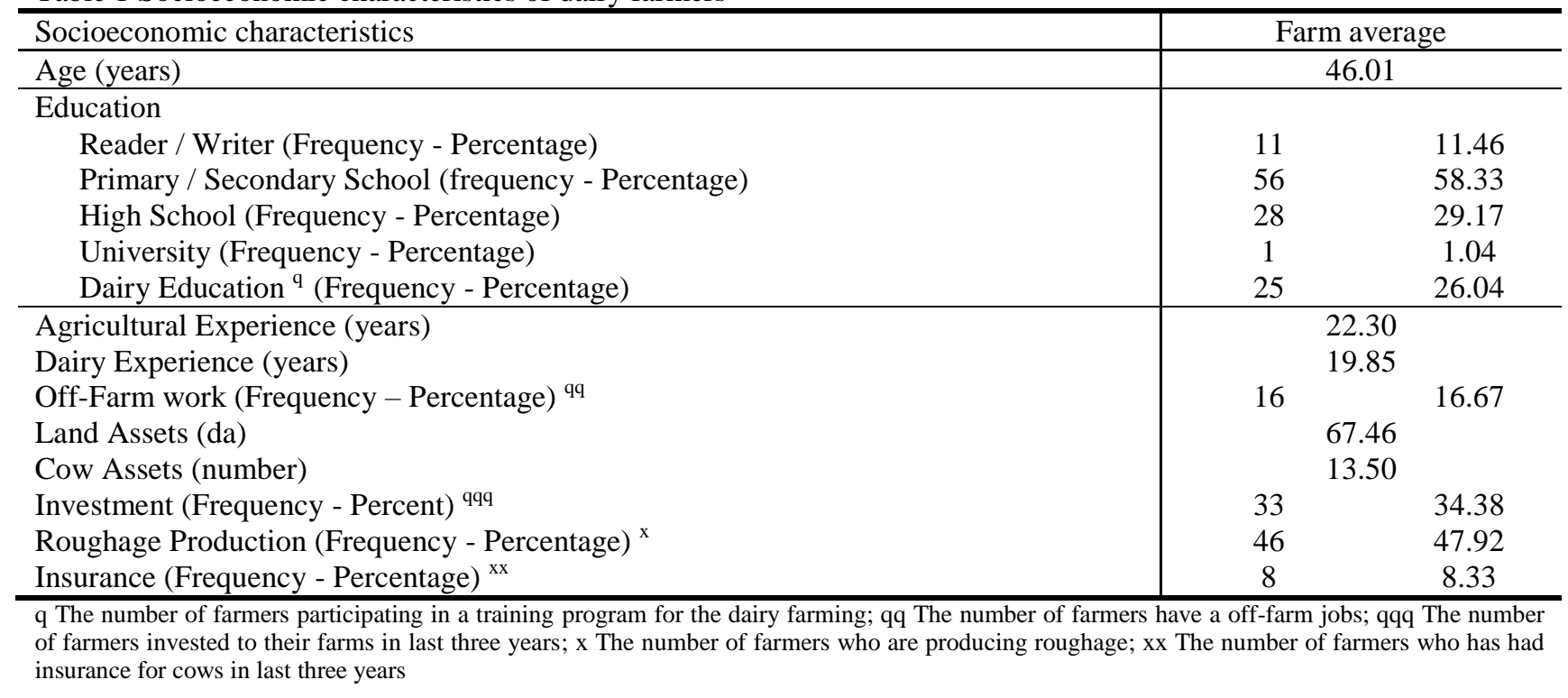

Table 2 Mean score for risk sources in dairy farming

\begin{tabular}{|c|c|c|}
\hline \multirow{2}{*}{ Risk sources } & \multicolumn{2}{|c|}{ Total Farmers } \\
\hline & Mean & SD \\
\hline Volatility in feed price & 4.90 & 0.37 \\
\hline Volatility in milk price & 4.79 & 0.48 \\
\hline Production diseases & 4.72 & 0.61 \\
\hline Misuse of drugs and other veterinary services & 4.59 & 0.78 \\
\hline Epidemic animal diseases & 4.57 & 0.64 \\
\hline Non-epidemic animal diseases & 4.50 & 0.78 \\
\hline Changes in government support policies for dairy cattle & 4.49 & 0.77 \\
\hline Variability in meat price & 4.35 & 0.82 \\
\hline Changes in the economic situation of Turkey & 4.31 & 0.80 \\
\hline Probability of lost key employee & 4.22 & 0.94 \\
\hline Low milk yield due to feed shortage & 4.07 & 0.82 \\
\hline The relationships between family members & 4.03 & 0.96 \\
\hline Inability to use modern technologies due to low capacity & 3.97 & 0.85 \\
\hline Likely to die of dairy cattle & 3.92 & 0.85 \\
\hline Changes in government policy on animal health and welfare & 3.89 & 1.14 \\
\hline Theft & 3.89 & 0.99 \\
\hline Animal pests such as ticks, etc. & 3.79 & 0.96 \\
\hline Labour costs & 3.51 & 1.39 \\
\hline Changes in interest rates & 3.44 & 1.19 \\
\hline Possibility of not marketing the milk & 3.42 & 1.15 \\
\hline Indebtedness and unable to repay debts & 3.42 & 0.96 \\
\hline Credit availability & 3.29 & 0.97 \\
\hline Changes in consumer preferences & 3.26 & 1.27 \\
\hline Lack of technical knowledge & 3.13 & 1.05 \\
\hline Changes in land values & 3.03 & 0.91 \\
\hline Lack of insurance for assets and dairy cows & 2.90 & 1.33 \\
\hline Waste management & 2.73 & 1.17 \\
\hline
\end{tabular}


Table 3 Result of factor analysis for risk source in dairy farming

\begin{tabular}{|c|c|c|c|c|c|c|c|c|}
\hline \multirow{2}{*}{ Risk Source } & \multicolumn{8}{|c|}{ Factors } \\
\hline & 1 & 2 & 3 & 4 & 5 & 6 & 7 & 8 \\
\hline Waste management & 0.780 & -0.117 & 0.173 & 0.179 & 0.020 & 0.153 & 0.183 & 0.035 \\
\hline Labour costs & 0.751 & 0.084 & -0.269 & 0.239 & 0.199 & -0.005 & 0.002 & -0.075 \\
\hline Lack of technical knowledge & 0.748 & -0.039 & 0.232 & 0.108 & 0.017 & 0.099 & -0.184 & 0.244 \\
\hline Changes in interest rates & 0.723 & 0.190 & 0.260 & 0.228 & 0.096 & 0.055 & 0.101 & -0.212 \\
\hline Theft & 0.019 & 0.750 & 0.128 & -0.096 & 0.034 & 0.170 & 0.306 & 0.117 \\
\hline Possibility of not marketing the milk & 0.044 & 0.744 & -0.193 & -0.194 & 0.038 & 0.161 & -0.165 & -0.037 \\
\hline Non-epidemic animal diseases & 0.135 & 0.613 & 0.128 & 0.563 & 0.295 & -0.205 & 0.011 & 0.003 \\
\hline Animal pests such as ticks, etc. & -0.044 & 0.581 & 0.505 & -0.050 & 0.005 & 0.149 & 0.163 & 0.126 \\
\hline Epidemic animal diseases & 0.140 & 0.579 & 0.404 & 0.421 & 0.072 & -0.055 & 0.100 & 0.042 \\
\hline Likely to die of dairy cattle & -0.159 & 0.546 & 0.302 & -0.083 & -0.153 & 0.345 & 0.340 & -0.056 \\
\hline Production diseases & 0.117 & 0.451 & 0.099 & 0.418 & 0.432 & -0.320 & -0.024 & -0.192 \\
\hline Changes in government policy on animal health and welfare & -0.058 & 0.143 & 0.775 & -0.085 & -0.063 & 0.122 & -0.135 & -0.206 \\
\hline Changes in government support policies for dairy cattle & 0.188 & 0.066 & 0.742 & 0.184 & 0.121 & 0.020 & -0.077 & 0.043 \\
\hline Changes in the economic situation of Turkey & 0.195 & -0.049 & 0.615 & -0.029 & 0.112 & -0.161 & 0.073 & -0.322 \\
\hline Changes in consumer preferences & 0.371 & 0.247 & 0.497 & 0.030 & -0.276 & 0.038 & 0.053 & 0.062 \\
\hline Probability of lost key employee & 0.191 & -0.243 & -0.071 & 0.761 & 0.147 & 0.093 & 0.079 & 0.160 \\
\hline Misuse of drugs and other veterinary services & 0.060 & 0.023 & 0.152 & 0.755 & 0.142 & -0.075 & 0.085 & 0.075 \\
\hline The relationships between family members & 0.364 & -0.031 & -0.128 & 0.746 & 0.040 & -0.023 & -0.028 & -0.067 \\
\hline Volatility in milk price & 0.001 & -0.005 & 0.092 & 0.227 & 0.837 & 0.089 & -0.128 & 0.139 \\
\hline Volatility in meat price & 0.209 & 0.135 & -0.179 & 0.036 & 0.784 & -0.047 & 0.035 & -0.217 \\
\hline Volatility in feed price & -0.063 & -0.029 & 0.305 & 0.281 & 0.595 & -0.118 & 0.273 & 0.360 \\
\hline Changes in land values & 0.054 & 0.137 & -0.023 & -0.075 & 0.030 & 0.844 & 0.111 & -0.117 \\
\hline Lack of insurance for assets and dairy cows & 0.342 & 0.219 & 0.148 & 0.023 & -0.084 & 0.648 & -0.151 & 0.256 \\
\hline Credit availability & 0.085 & 0.197 & -0.151 & 0.165 & 0.011 & 0.105 & 0.769 & -0.208 \\
\hline Indebtedness and unable to repay debts & 0.467 & 0.032 & 0.172 & -0.053 & -0.138 & -0.278 & 0.498 & 0.214 \\
\hline Inability to use modern technologies due to low capacity & 0.123 & 0.032 & -0.144 & 0.062 & -0.028 & -0.012 & -0.155 & 0.733 \\
\hline Low milk yield due to feed shortage & -0.152 & 0.132 & -0.336 & 0.094 & 0.175 & 0.027 & 0.398 & 0.519 \\
\hline Explained variance $(\%)$ & 20.31 & 13.07 & 9.62 & 8.04 & 5.55 & 5.46 & 4.18 & 4.02 \\
\hline
\end{tabular}

Table 4 Mean score for risk management strategies in dairy farming

\begin{tabular}{|c|c|c|}
\hline \multirow{2}{*}{ Risk Management Strategies } & \multicolumn{2}{|c|}{ Total Farmers } \\
\hline & Mean & SD \\
\hline Take precautions to prevent disease & 4.66 & 0.56 \\
\hline To produce the lowest possible cost (ceteris paribus) & 4.57 & 0.63 \\
\hline Work with appropriate to climate conditions and highly efficient animal breeds & 4.55 & 0.58 \\
\hline Farmers union membership - Cooperative partnership & 4.49 & 0.73 \\
\hline Make the crop production beside livestock & 4.45 & 0.96 \\
\hline Division of labour among family members & 4.15 & 1.10 \\
\hline To collect market information & 3.98 & 1.26 \\
\hline Work with modern machinery / equipment & 3.95 & 0.86 \\
\hline Make production in multiple fields & 3.93 & 1.02 \\
\hline Keeping cash & 3.83 & 0.82 \\
\hline Keeping farm record regularly & 3.81 & 1.07 \\
\hline Planning expenditure & 3.81 & 1.10 \\
\hline Diversification of products which supply to the market by farmer union & 3.58 & 1.64 \\
\hline To obtain non-farm income & 3.31 & 1.24 \\
\hline To benefit from technical consultancy services & 3.21 & 1.14 \\
\hline Appling strict hygiene rules & 3.20 & 1.41 \\
\hline Off-farm investment & 3.10 & 1.24 \\
\hline Making insurance for animal and assets & 2.77 & 1.40 \\
\hline To participate in the extension service for dairy farmers & 2.72 & 1.13 \\
\hline Dept management & 2.67 & 1.26 \\
\hline Making personnel insurance & 2.35 & 1.31 \\
\hline Family members working off-farm & 2.29 & 1.20 \\
\hline Family members working in other farms & 2.27 & 1.25 \\
\hline
\end{tabular}


Table 5 Results of factor analysis for risk management strategies in dairy farming

\begin{tabular}{|c|c|c|c|c|c|c|}
\hline \multirow{2}{*}{ Risk Management Strategies } & \multicolumn{6}{|c|}{ Factors } \\
\hline & 1 & 2 & 3 & 4 & 5 & 6 \\
\hline Making insurance for animal and assets & 0.828 & 0.079 & -0.052 & 0.087 & -0.121 & 0.054 \\
\hline Making personnel insurance & 0.810 & 0.012 & -0.150 & -0.126 & 0.201 & 0.042 \\
\hline Dept management & 0.799 & -0.033 & -0.260 & 0.032 & 0.132 & -0.013 \\
\hline Applying strict hygiene rules & 0.770 & -0.420 & 0.070 & -0.057 & -0.077 & -0.080 \\
\hline To collect market information & 0.737 & -0.349 & 0.249 & 0.009 & 0.019 & -0.003 \\
\hline Planning expenditure & 0.663 & -0.010 & 0.386 & 0.078 & 0.063 & 0.250 \\
\hline Diversification of products which supply to the market by farmer union & 0.607 & -0.379 & 0.307 & -0.133 & -0.222 & 0.082 \\
\hline Off-farm investment & -0.053 & 0.824 & -0.022 & -0.015 & 0.128 & 0.010 \\
\hline To obtain non-farm income & -0.176 & 0.713 & 0.067 & 0.184 & 0.100 & 0.108 \\
\hline Make production in multiple fields & -0.115 & 0.633 & 0.162 & 0.189 & 0.363 & -0.015 \\
\hline Keeping farm record regularly & 0.036 & 0.618 & 0.353 & -0.334 & 0.353 & -0.146 \\
\hline Keeping cash & -0.179 & 0.127 & 0.783 & -0.040 & 0.090 & -0.019 \\
\hline Work with modern machinery / equipment & 0.189 & 0.121 & 0.710 & 0.000 & 0.121 & 0.100 \\
\hline Take precautions to prevent disease & -0.030 & -0.409 & 0.532 & 0.264 & 0.360 & -0.254 \\
\hline Make the crop production beside livestock & 0.069 & 0.061 & -0.070 & 0.829 & -0.025 & -0.054 \\
\hline Farmers union membership - Cooperative partnership & 0.365 & -0.082 & 0.114 & 0.662 & -0.038 & 0.277 \\
\hline Family members working off-farm & 0.452 & -0.183 & 0.004 & -0.662 & 0.000 & 0.135 \\
\hline Family members working in other farms & 0.434 & -0.436 & -0.094 & -0.494 & -0.052 & 0.150 \\
\hline To produce the lowest possible cost (ceteris paribus) & 0.007 & 0.259 & 0.070 & 0.031 & 0.813 & 0.061 \\
\hline Work with appropriate to climate conditions and highly efficient animal breeds & 0.099 & 0.230 & 0.200 & -0.104 & 0.761 & 0.096 \\
\hline Division of labour among family members & 0.394 & -0.002 & 0.208 & 0.111 & -0.232 & -0.686 \\
\hline To participate in the extension service for dairy farmers & 0.420 & -0.048 & 0.104 & 0.033 & 0.078 & 0.562 \\
\hline To benefit from technical consultancy services & 0.396 & 0.202 & 0.246 & 0.050 & -0.156 & 0.467 \\
\hline
\end{tabular}

Result of this study indicate that dairy farmers consider take precautions to prevent disease, producing the lowest possible cost (ceteris paribus) and work with appropriate to climate conditions and highly efficient animal breeds the most important risk management strategies in dairy farming. Gebreegziabher and Tadesse (2014) reported applying strict hygiene rules, main operator working off-farm and, use of veterinary service the most important risk management strategies in dairy farming in Ethiopia. To participate in the extension service for dairy farmers and applying strict hygiene rules identified as a less important risk managements strategies in Adana province. Producing at the lowest cost, prevent/reduce livestock diseases and using consultant service or consultant extension workers were identified as the most important three risk management strategies in another study conducted in China (Zhou et al., 2012). Keeping dept low, producing at the lowest cost, reducing livestock disease were identified the most important risk factors affecting dairy farming in Antalya province of Turkey (Akcaoz et al., 2009; K1zılay, 2006). The result of a study conducted in Norway by Flaten et al. (2005) indicated that dairy farmers perceive that liquidity - keep cash in hand, prevent / reducing livestock diseases and buying farm insurance were the most important risk management strategies. Taking into account findings from studies carried out in countries with different levels of development, dairy farmers' perceived producing the lowest possible cost (ceteris paribus), use of veterinary service and prevent / reducing livestock diseases as the most important risk management strategies.
Relationship between Risk Perceptions and Socioeconomic Variables/Communication Behaviour

In order to examine relationship between farmers' perception and socioeconomic variables / communication behaviour, multiple regression models carried out in this study.

Relationship between Risk Sources and Socioeconomic Variables/Communication Behaviour

The regression coefficients and p-values of the models are presented in Table 6. All models were highly significant except one and all of them explained around 25- $50 \%$ of the total variance. All socioeconomic variables and communication behaviour had at least one significant relationship with the risk sources. In contrast, earlier studies have found some relationships between socioeconomic variables and farmers' perceptions of risk sources and management responses (Agir et al., 2015; Flaten et al., 2005; Meuwissen et al., 2001).

In our study, $\mathrm{R}^{2}$ of models establish for technology and cost, production and marketing, political and economic, veterinary services and human sources, price risks, land value and insurance risks, financial risks and feed shortage and low capacity were $0.242,0.372,0.571$, $0.330,0.157,0.252,0.380$, and 0.328 respectively. Dairy cattle training positively, free veterinarian / agricultural engineers and television variables negatively related to technology and cost risk. Television and forage production variables positively and internet variable negatively related to production and marketing risk. Ministry of Food, Agriculture and Livestock (MFAL) variable positively, investment, internet and off-farm work variables negatively related to political and 
economic risk. Age, land size, television and free veterinarian / agricultural engineer variable negatively, insurance and dairy farming experience variable positively related to veterinary services and human sources risk. Education, investment and insurance variable positively related to land value and insurance risks. Dairy cattle training, television, agricultural experience, insurance and land size variables positively, age and off-farm work variables negatively related to financial risks. Land size and cow (number) variables negatively related to feed shortage and low capacity risk (Table 6).

Table 6 Relationship between risk sources and socioeconomic variables/communication behaviour

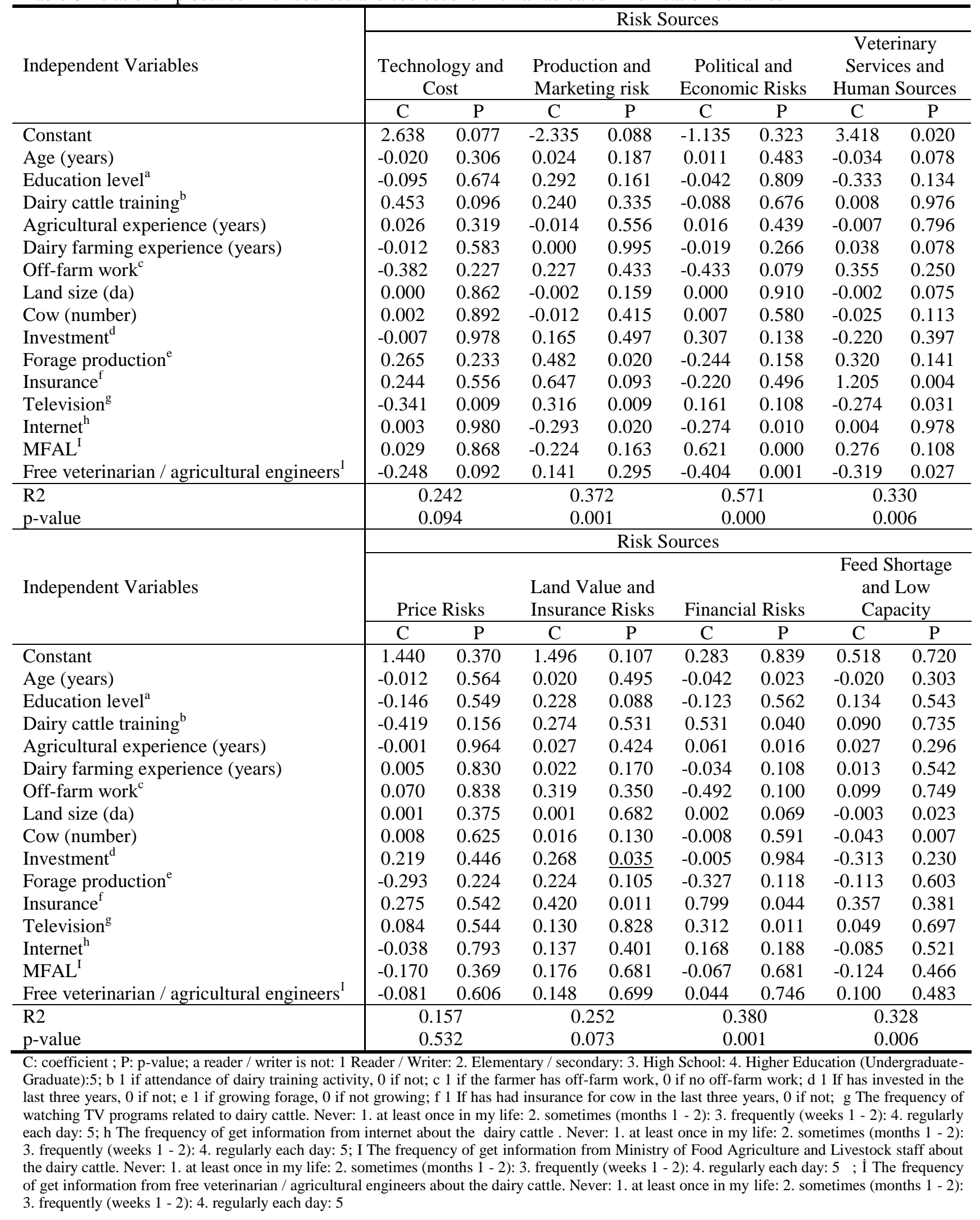


Relationship between Risk Management Strategies and Socioeconomic Variables/Communication Behaviour

The regression coefficients and p-values of the models are presented in Table 7. All models were highly significant and all of them explained around 25-50\% of the total variance. All socioeconomic variables and communication behaviour had at least one significant relationship with the risk management strategies. In contrast, earlier studies have found some relationships between socioeconomic variables and farmers' perceptions of risk sources and management responses (Agir et al., 2015; Flaten et al., 2005; Meuwissen et al., 2001).

Table 7 Relationship between risk management strategies and socioeconomic variables/communication behaviour

\begin{tabular}{|c|c|c|c|c|c|c|}
\hline \multirow{3}{*}{ Independent Variables } & \multicolumn{6}{|c|}{ Risk Management Strategies } \\
\hline & \multicolumn{2}{|c|}{$\begin{array}{l}\text { Planning and } \\
\text { Insurance }\end{array}$} & \multicolumn{2}{|c|}{$\begin{array}{l}\text { Off-Farm Income and } \\
\text { Diversification of } \\
\text { Production }\end{array}$} & \multicolumn{2}{|c|}{$\begin{array}{l}\text { Flexibility and } \\
\text { Prudence }\end{array}$} \\
\hline & $\mathrm{C}$ & $\mathrm{P}$ & $\mathrm{C}$ & $\mathrm{P}$ & $\mathrm{C}$ & $\mathrm{P}$ \\
\hline Constant & 0.922 & 0.472 & -1.612 & 0.200 & -1.730 & 0.235 \\
\hline Age (years) & -0.016 & 0.331 & 0.003 & 0.850 & -0.008 & 0.688 \\
\hline Education level $^{\mathrm{a}}$ & 0.009 & 0.965 & 0.069 & 0.719 & 0.210 & 0.344 \\
\hline Dairy cattle training $^{\mathrm{b}}$ & 0.706 & 0.003 & 0.617 & 0.008 & -0.310 & 0.245 \\
\hline Agricultural experience (years) & 0.045 & 0.055 & 0.041 & 0.071 & -0.014 & 0.579 \\
\hline Dairy farming experience (years) & -0.022 & 0.255 & -0.017 & 0.369 & 0.018 & 0.418 \\
\hline Off-farm work ${ }^{c}$ & -0.808 & 0.004 & 0.217 & 0.417 & 0.109 & 0.724 \\
\hline Land size (da) & 0.000 & 0.666 & 0.002 & 0.096 & -0.001 & 0.321 \\
\hline Cow (number) & -0.018 & 0.194 & -0.015 & 0.272 & 0.022 & 0.148 \\
\hline Investment $^{\mathrm{d}}$ & 0.030 & 0.896 & -0.220 & 0.328 & 0.237 & 0.363 \\
\hline Forage production ${ }^{\mathrm{e}}$ & 0.300 & 0.120 & -0.138 & 0.462 & 0.317 & 0.147 \\
\hline Insurance $^{\mathrm{f}}$ & 1.084 & 0.003 & 0.780 & 0.029 & 0.522 & 0.202 \\
\hline Television ${ }^{\mathrm{g}}$ & 0.022 & 0.840 & 0.136 & 0.214 & 0.218 & 0.086 \\
\hline Internet $^{\mathrm{h}}$ & -0.050 & 0.669 & 0.161 & 0.161 & 0.030 & 0.819 \\
\hline MFAL $^{\mathrm{I}}$ & 0.086 & 0.570 & -0.507 & 0.001 & -0.201 & 0.241 \\
\hline Free veterinarian / agricultural engineers ${ }^{\mathrm{I}}$ & -0.324 & 0.012 & 0.463 & 0.000 & 0.230 & 0.112 \\
\hline & & & & & & \\
\hline $\mathrm{p}$-value & & & & & & \\
\hline \multirow{3}{*}{ Independent Variables } & \multicolumn{6}{|c|}{ Risk Management Strategies } \\
\hline & \multicolumn{2}{|c|}{$\begin{array}{c}\text { Farmer Organization } \\
\text { and Income } \\
\text { Diversification }\end{array}$} & \multicolumn{2}{|c|}{ Cost Reduction } & \multicolumn{2}{|c|}{$\begin{array}{l}\text { Labour Division and } \\
\text { Consultancy }\end{array}$} \\
\hline & $\mathrm{C}$ & $\mathrm{P}$ & $\mathrm{C}$ & $\mathrm{P}$ & $\mathrm{C}$ & $\mathrm{P}$ \\
\hline Constant & 1.117 & 0.342 & -4.720 & 0.001 & -2.894 & 0.058 \\
\hline Age (years) & -0.033 & 0.034 & 0.034 & 0.077 & 0.001 & 0.953 \\
\hline Education level $^{\mathrm{a}}$ & 0.059 & 0.744 & 0.326 & 0.140 & 0.274 & 0.236 \\
\hline Dairy cattle training $^{\mathrm{b}}$ & -0.024 & 0.911 & -0.120 & 0.649 & -0.075 & 0.787 \\
\hline Agricultural experience (years) & 0.011 & 0.611 & -0.033 & 0.202 & 0.025 & 0.351 \\
\hline Dairy farming experience (years) & 0.023 & 0.186 & 0.016 & 0.447 & -0.001 & 0.955 \\
\hline Off-farm work ${ }^{c}$ & 0.543 & 0.032 & 0.321 & 0.295 & -0.154 & 0.633 \\
\hline Land size (da) & 0.001 & 0.422 & 0.000 & 0.810 & -0.001 & 0.324 \\
\hline Cow (number) & 0.018 & 0.151 & 0.008 & 0.614 & 0.000 & 0.957 \\
\hline Investment $^{\mathrm{d}}$ & -0.194 & 0.358 & 0.272 & 0.293 & -0.260 & 0.339 \\
\hline Forage production ${ }^{\mathrm{e}}$ & -0.349 & 0.050 & 0.147 & 0.495 & -0.073 & 0.746 \\
\hline Insurance $^{\mathrm{f}}$ & 0.404 & 0.222 & 0.308 & 0.445 & 0.346 & 0.416 \\
\hline Television $^{\mathrm{g}}$ & -0.199 & 0.053 & 0.404 & 0.002 & -0.035 & 0.792 \\
\hline Internet $^{\mathrm{h}}$ & 0.169 & 0.118 & 0.009 & 0.948 & 0.174 & 0.209 \\
\hline MFAL $^{\mathrm{I}}$ & 0.319 & 0.023 & 0.178 & 0.294 & 0.517 & 0.005 \\
\hline Free veterinarian / agricultural engineers ${ }^{\mathrm{I}}$ & -0.359 & 0.003 & 0.039 & 0.782 & -0.031 & 0.835 \\
\hline $\mathrm{R} 2$ & \multicolumn{2}{|c|}{0.499} & \multicolumn{2}{|c|}{0.315} & \multicolumn{2}{|c|}{0.243} \\
\hline p-value & \multicolumn{2}{|c|}{0.000} & \multicolumn{2}{|c|}{0.010} & \multicolumn{2}{|c|}{0.092} \\
\hline \multicolumn{7}{|c|}{$\begin{array}{l}\text { C: coefficient; P: p-value; a reader / writer is not: } 1 \text { Reader / Writer: } 2 \text {. Elementary / secondary: } 3 \text {. High School: } 4 \text {. Higher Education (Undergraduate- } \\
\text { Graduate); b } 1 \text { if attendance of dairy training activity, } 0 \text { if not; } \mathrm{c} 1 \text { if the farmer has off-farm work, } 0 \text { if no off-farm work; } 1 \text { If has invested in the last } \\
\text { three years, } 0 \text { if not; } 11 \text { if growing forage, } 0 \text { if not growing; } 1 \text { If has had insurance for cow in the last three years, } 0 \text { if not; g The frequency of } \\
\text { watching TV programs related to dairy cattle. Never: } 1 \text {. at least once in my life: } 2 \text {. sometimes (months } 1-2 \text { ): } 3 \text {. frequently (weeks } 1-2 \text { ): } 4 \text {. regularly } \\
\text { each day: } 5 \text {; h The frequency of get information from internet about the dairy cattle. Never: } 1 \text {. at least once in my life: } 2 \text {. sometimes (months } 1-2 \text { ): } \\
\text { 3. frequently (weeks } 1-2 \text { ): } 4 \text {. regularly each day: } 5 \text {; I The frequency of get information from Ministry of Food Agriculture and Livestock staff about } \\
\text { the dairy cattle. Never: } 1 \text {. at least once in my life: } 2 \text {. sometimes (months } 1-2 \text { ): } 3 \text {. frequently (weeks } 1-2 \text { ): } 4 \text {. regularly each day: } 5\end{array}$} \\
\hline
\end{tabular}


In our study, $\mathrm{R}^{2}$ of models establish for planning and insurance, off-farm income and diversification of production, flexibility and prudence, farmer organization and income diversification, cost reduction and labour division and consultancy were $0.441,0.448,0.275,0.499$, 0.315 and 0.243 , respectively. Insurance, agricultural experience and dairy cattle training variables positively, free veterinarian / agricultural engineers and off-farm work variables negatively related to planning and insurance factor. Dairy cattle training, agricultural experience, land size, insurance and free veterinarian / agricultural engineer variables positively, MFAL variable negatively related to off-farm income and diversification of production factor. Only one variable, farmers' frequency of receiving information from television about the dairy cattle positively related to flexibility and prudence factor. MFAL and off-farm work variables positively, age, forage production, television and free veterinarian / agricultural engineer variables negatively related to farmer organization and income diversification factor. Television and age variables positively related to cost reduction factor. MFAL variable positively related to labour division and consultancy factor (Table 7).

\section{Discussion}

In order to examine dairy farmers' risk perception, a scale used consists of 27 items and its Cronbach's Alpha was 0.808 . The most important risk sources that the farmers' perceive were volatility in feed price, volatility in milk price, production diseases, misuse of drugs and other veterinary services and epidemic animal diseases. In order to examine dairy farmers' risk management strategies, a scale used consists of 23 items and its Cronbach's Alpha was 0.775 . The most important risk management strategies that the farmers' perceive were take precautions to prevent disease, to produce the lowest possible cost (ceteris paribus), work with appropriate to climate conditions and highly efficient animal breeds. It is suggested that the most effective measures that can be taken farmers organization and contract farming against fluctuations in the price of milk and feed. Through farmer organization, dairy farmers could control supply amount and they can be reach production level for establish an effective marketing network. And also, through the veterinarian, agriculture or food engineer will be employed within farmer organization, can be enable a better production quality and taken measures against the disease. Via contract farming, dairy farmers could be guaranteed a certain price level and they could apply to strict hygiene rules in order to fulfil the contract terms. Also included in the contract as buyer industrial enterprises could also provide technical support to producers. The fourth most important source of risk according to farmers' perceived was defined as misuse of veterinary drugs and other veterinary services. And in this risk group, the most important issue was artificial insemination. It could be provided technical support to farmers in order to appropriately determine the estrus of dairy cows. In addition, difficulties have been experienced some issue such as qualified technical staff and quality semen. It is important development of dairy cattle in Adana province that artificial insemination services supported by the public. According to the farmer perception, the most important risk factors are identified as volatility in price milk and feed. It is need that advanced research about price risk management. Multiple regression analysis was used to study examine relationship between farmers' risk perception and socioeconomic variables / communication behaviour. A number of socio-economic variables and communication behaviour such as television, MFAL staff and internet were found to be related to risk and risk management. These communication networks could be used in order to create awareness and inform to farmers about risk management.

\section{References}

Agır HB, Saner G, Adanacioglu H. 2015. Risk sources encountered by farmers in the open field production of strawberry and risk management strategies: a case of Menemen - Emiralen District of Izmir. Journal of Agricultural Sciences, 21: 13 - 25.

Akcaoz H, Kizilay H, Ozcatalbas O. 2009. Risk management strategies in dairy farming: A case study in Turkey. Journal of Animal and Veterinary Advances, 8 (5): 949 - 958.

Akcaoz H, Kizilay H, Ozcatalbas O. 2010. Risk and sustainability in tobacco production in Turkey. Journal of Food, Agriculture \& Environment, 8 (3,4): 717 - 722.

Akcaoz H, Ozkan B. 2005. Determining risk sources and strategies among farmers of contrasting risk awareness: A case study for Cukurova region of Turkey. Journal of Arid Environments, 62(4): 661-675.

Alpar R. 2011. Uygulamalı Çok Değişkenli İstatistiksel Yöntemler (3. Baskı). Ankara: Detay Yayıncılık.

Anonymous. 2015. www.tuik.gov.tr. (Access date: 15 Ekim 2015).

Ceyhan V. 2003. Tarım işletmelerinde risk analizi: Çorum İli Kızılırmak Havzası örneği. Samsun: Ondokuz Mayıs Üniversitesi, Ziraat Fakültesi.

Ceyhan V, Bozoğlu M, Cinemre H. 2003. Measuring yield and price risks for dairy farms and designing risk management strategies: the case of Tonya, Turkey. Bodenkultur, 54(4): $215-220$.

Cukur F, Saner G, Cukur T, Dayan V. 2011. Risks and risk strategies on olive farming in Milas district of Mugla province, Turkey. Journal of Food, Agriculture \& Environment, 9(1): 190 - 194.

Flaten O, Lien G, Koesling M, Valle PS, Ebbesvik M. 2005. Comparing risk perceptions and risk management in organic and conventional dairy farming: empirical results from Norway. Livestock Production Science, 95(1): 11-25.

Gebreegziabher K, Tadesse T. 2014. Risk perception and management in smallholder dairy farming in Tigray, Northern Ethiopia. Journal of Risk Research, 17(3): 367 381.

Hair FJ, Anderson JR, Tatham RZ, Black WC. 1994. Multivariate data analysis. New York: McMillan Publishing Company. 3rd Edition.

Hardaker J, Huirne R, Anderson J, Lien G. 2004. Coping with risk in agriculture. CABI: 1. edition.

Hazneci E, Ceyhan V. 2011. Amasya ili Merzifon ilçesinde süt sığırcılığı yapan tarım işletmelerinde risk analizi. Akdeniz Üniversitesi Ziraat Fakültesi Dergisi, 24(2): 109-114.

Hoag D. 2009. Applied risk management in agriculture. United States: CRC Press; 1 edition.

Kalaycı Ş. 2008. SPSS Uygulamalı Çok Değişkenli İstatistik Teknikleri. İstanbul: Asil Yayın Dağıtım. 
Kaya HI, Konar N, Artık N. 2014. Türkiye'de kentli tüketicilerin genetik modifiye organizman ve gidalara yönelik tutumları. Tarım Bilimleri Dergisi, 20 (1): 71 - 82.

Kızılay H. 2006. Antalya İli'nde süt sığırı yetişticileri birliğine üye olan ve olmayan işletmelerde risk analizi. Akdeniz Üniversitesi Fen Bilimleri Enstitüsü Tarım Ekonomisi Anabilim Dalı Yüksek Lisans Tezi (Basılmamış). Antalya.
Meuwissen M, Huirne R, Hardaker J. 2001. Risk and risk management: an empirical analysis of Dutch livestock farmers. Livestock Production Science 69: 43 - 53.

Zhou H, Nanseki T, Takeuchi S. 2012. Dairy farmers' risk perception and risk management in China - evidence from Hebesi Province and Inner Mongolia. Agricultural Information Research, 21(2): 20 - 27. 